Arnis Puspitha R: Pendampingan Posyandu Lanjut Usia

\title{
Pendampingan Posyandu Lanjut Usia
}

\author{
Arnis Puspitha $\mathbf{R}^{1}$, Nurhaya Nurdin ${ }^{1}$, Umniyah Saleh ${ }^{2}$ \\ ${ }^{1}$ Fakultas Keperawatan Unhas, 2Fakultas Kedokteran Unhas \\ Email: arnis.puspitha@yahoo.com
}

\begin{abstract}
Abstrak
Kota Makassar memiliki jumlah lanjut usia (lansia) terbanyak kedua di Sulawesi Selatan yaitu sebanyak 79.581 jiwa. Salah satu kelurahan di kota Makassar yaitu kelurahan Paccerakkang Kecamatan Biringkanaya terdapat 487 jiwa lansia yang tersebar di 8 RW. Sembilanpuluh persen lansia mengalami hipertensi, rheumatoid arthritis, infeksi saluran pernapasan atas, diabetes mellitus, gastritis, dan stroke, penglihatan kabur yang menyebabkan risiko jatuh, tetapi belum mendapat pelayanan kesehatan yang memadai. Selain itu, posyandu lansia di 3 RW masih bergabung dengan Posyandu balita, jumlah kunjungan lansia pun masih sangat rendah, sementara 5 RW lainnya belum memiliki Posyandu lansia. Selain itu jumlah petugas kesehatan sangat terbatas yakni hanya 1 orang. Dengan demikian, pelaksanaannya belum berfungsi optimal, bahkan tidak mampu menyentuh kebutuhan para lansia. Tujuan pendampingan Posyandu ini untuk meningkatkan kesejahteraan lansia, baik fisik maupun psikologis, melalui kegiatan Posyandu lansia yang mandiri. Metode kegiatan ini dilaksanakan dalam tiga tahap yaitu pelatihan kader kesehatan lansia, pembentukan kelompok kerja (pokja) lansia, dan pendampingan pelaksanaan Posyandu lansia sistem 5 meja. Hasil dari kegiatan ini adalah adanya peningkatan pengetahuan yang cukup tentang kesehatannya, dapat mempertahankan kebugaran dan kesehatan fisik serta kesehatan psikologisnya. Posyandu lansia ini berdampak pada peningkatan derajat kesehatan baik fisik maupun psikologis dan usia harapan hidup lansia sehingga dapat mencapai masa tua yang bahagia dan berdaya guna dalam kehidupan keluarga dan masyarakat.
\end{abstract}

Kata kunci: Hidup Sehat, lanjut usia, posyandu.

\begin{abstract}
Makassar City has the second largest number of elderly (elderly) in South Sulawesi which is 79,581 people. One of the villages in the city of Makassar, Paccerakkang Village, Biringkanaya Subdistrict, has 487 elderly people scattered in $8 \mathrm{RWs}$. Around 90\% of elderly suffer from hypertension, rheumatoid arthritis, upper respiratory tract infections, diabetes mellitus, gastritis, and stroke, blurred vision that causes the risk of falling, but have not received adequate health services. In addition, elderly Posyandu in 3 areas of $R W$ still join Posyandu toddlers, elderly visits is still very low, while the other $5 \mathrm{RWs}$ do not have an elderly Posyandu, health workers is very limited, only one person. Therefore, the implementation has not been functioning optimally, even unable to touch the needs of the elderly. This program aims to improve the welfare of the elderly, both physically and psychologically, through independent Posyandu elderly activities. The method of this activity was carried out in three stages: health cadre training, establish elderly working groups, and assistance for the implementation of the Posyandu for the elderly with five table system. The result is the increased knowledge about their health, can maintain fitness and physical health and psychological health. The elderly Posyandu has an impact on improving the health status and life expectancy of the elderly, so that they can reach a happy and efficient old age in family and community life.
\end{abstract}

Keywords: Elderly, Healthy Life, Posyandu. 


\section{Pendahuluan}

Pembangunan nasional di berbagai bidang telah memperbaiki kualitas kesehatan dan kondisi sosial ekonomi masyarakat secara umum. Hasil sensus penduduk (2010) menunjukkan bahwa penduduk Indonesia memiliki harapan untuk hidup hingga mencapai usia 70,7 tahun. Sementara Usia Harapan Hidup (UHH) pada tahun 2015 adalah 70 tahun, dan beranjak lebih tinggi mencapai 72 tahun pada tahun 2016. Meningkatnya angka harapan hidup telah menambah jumlah penduduk lanjut usia (lansia) dan merubah struktur penduduk Indonesia (Maryam \& Siti, 2011).

Usia 60 tahun ke atas merupakan tahap akhir dari proses penuaan yang memiliki dampak terhadap tiga aspek, yaitu biologis, ekonomi, dan sosial. Secara biologis, lansia akan mengalami proses penuaan secara terus menerus yang ditandai dengan penurunan daya tahan fisik dan rentan terhadap serangan penyakit. Jumlah lansia di Indonesia mencapai 20,24 juta jiwa, setara dengan 8,03\% dari seluruh penduduk Indonesia pada tahun 2014 (BPS, 2015).

Peningkatan populasi lansia di Indonesia dapat menimbulkan permasalahan terkait aspek medis, psikologis, ekonomi, dan sosial sehingga diperlukan peningkatan pelayanan kesehatan. Pelayanan kesehatan harus diberikan secara maksimal untuk memenuhi hak lansia. Pos Pelayanan Terpadu Lanjut Usia (Posyandu Lansia) adalah suatu wadah pelayanan kepada lanjut usia di masyarakat, yang proses pembentukan dan pelaksanaannya dilakukan oleh masyarakat dengan menitikberatkan pelayanan kesehatan pada upaya promotif dan preventif. Dari Data Kementerian Kesehatan, saat ini jumlah Posyandu Lansia yang memberikan pelayanan promotif dan preventif ada 69.500 yang tersebar di semua provinsi di Indonesia. Namun, implementasi posyandu lansia saat ini belum berjalan maksimal (Kemenkes, 2016).

Kota Makassar menempati jumlah lansia terbanyak kedua di Sulawesi selatan setelah kabupaten bone, yaitu sebanyak 79.581 jiwa. Salah satu kelurahan di kota Makassar yaitu kelurahan Paccerakkang Kecamatan Biringkanaya terdapat 485 jiwa lansia yang tersebar di 7 RW. Di kelurahan Paccerakkang, posyandu lansia bergabung dengan posyandu bayi balita, jumlah kunjungan lansia pun masih sangat rendah. Dengan demikian, pelaksanaanya belum berfungsi optimal, bahkan tidak mampu menyentuh kebutuhan para lansia. 
Tabel 1. Jumlah Lansia di Kelurahan Paccerakkang setelah pemekaran

\begin{tabular}{cc}
\hline Jumlah RW & Jumlah Lansia \\
\hline RW-1 & 99 jiwa \\
RW-2 & 113 jiwa \\
RW-3 & 103 jiwa \\
RW-4 & 46 jiwa \\
RW-5 & 51 jiwa \\
RW-6 & 30 jiwa \\
RW-7 & 55 jiwa \\
Total & $\mathbf{4 9 7}$ jiwa \\
\hline
\end{tabular}

(Sumber : Data Kelurahan Paccerakkang Tahun 2016)

Secara ringkas, 10 penyakit tertinggi pada yang diderita oleh lansia di kelurahan Paccerakkang pada tahun 2016 dipaparkan dalam tabel 1.2 berikut:

\begin{tabular}{l} 
Tabel 2. Penyakit Lansia Tertinggi di Kelurahan Paccerakkang \\
\hline Penyakit pada Lansia \\
\hline Hipertensi (tekanan darah tinggi) \\
Rheumatoid Arthritis (Rematik) / Nyeri Sendi \\
Infeksi Saluran Pernapasan Atas (ISPA) \\
Diabetes Mellitus (kencing manis) \\
Gastritis (maag) \\
Stroke \\
Anemia \\
Myalgia (sakit kepala) \\
\hline Katarak \\
Gangguan Vaskuler (penyakit jantung) \\
(Sumber: Data Puskesmas Paccerakkang Nopember-Desember 2016)
\end{tabular}

Program Kemitraan Masyarakat (PKM) melalui pendampingan Posyandu Lansia ini diharapkan dapat memberikan manfaat bagi peningkatan usia harapan hidup dan derajat kesehatan lansia di kelurahan Paccerakkang, serta diharapkan menjadi posyandu lansia percontohan di kota Makassar. Permasalahan yang dihadapi mitra adalah posyandu Lansia belum berfungsi optimal di kelurahan Paccerakkang dengan kondisi posyandu lansia digabung dengan posyandu bayi dan balita, kader posyandu tidak memiliki pengetahuan yang memadai, jumlah petugas kesehatan dan kader kesehatan sangat terbatas. Masalah lainnya adalah jumlah lansia di kelurahan Paccerakkang sebanyak 485 jiwa belum mendapat pelayanan kesehatan yang mamadai dan banyaknya lansia yang menderita penyakit degeneratif seperti hipertensi (tekanan darah tinggi), rematik, diabetes mellitus (penyakit kencing manis), gastritis (maag), infeksi saluran pernapasan atas (ISPA), stroke, penglihatan kabur yang menyebabkan risiko jatuh, dan lain-lain tetapi tidak ditindaklanjuti secara berkesinambungan. 


\section{Metode}

Pelaksanaan kegiatan pengabdian ini dilakukan pada bulan April - Nopember 2018 di Kelurahan Paccerakkang Kota Makassar. Kegiatan ini meliputi 3 (tiga) tahap, yaitu Pelatihan Kader

Kesehatan Lansia, Pembentukan Kelompok Kerja (Pokja) Lansia, dan Pendampingan Pelaksanaan Posyandu Lansia Sistem 5 Meja. Rancangan pelaksanaan kegiatan pendampingan posyandu lansia meliputi 4 tahap yaitu pelatihan kader kesehatab, pembentukan pokja, pendampingan posyandu dan evaluasi pelaksanaan. Buat narasi yang lebih sistematis.

\section{Pelatihan Kader Kesehatan Lansia}

Pelatihan ini diikuti oleh 24 orang kader kesehatan dari 8 RW di kelurahan Paccerakkang.

Kegiatan pelatihan meliputi pemberian materi-materi :
a. Urgensi Posyandu Lansia
b. Tugas, peran, dan fungsi kader kesehatan dalam masyarakat
c. Penyakit terbanyak pada Lansia
d. Tahap-tahap pelaksanaan Posyandu Lansia Sistem 5 Meja
e. Cara pengisian KMS Lansia
f. Teknik penyuluhan dan konseling pad lansia

\section{Pembentukan Kelompok Kerja (Pokja) Lansia dan Pendampingan Aktifitas Pelayanan Pokja}

Pokja lansia bertugas melayani dan mendampingi lansia, termasuk proaktif menjemput ke rumah lansia jika lansia tersebut sulit menjangkau posyandu atau fasilitas pelayanan kesehatan. Pokja lansia juga mengaktifkan senam lansia setiap minggu.

\section{Pendampingan Pelaksanaan Posyandu Lansia Sistem 5 Meja}

Posyandu lansia diikuti oleh seluruh lansia di kelurahan Paccerakkang, meliputi :

a. Penerapan konsep pelayanan Posyandu Lansia Sistem 5 Meja dengan urutan tahapan sebagai berikut :

Meja 1: Pendafaran lansia

Meja 2: Penimbangan berat badan dan pengukuran tinggi badan lansia, dicatat pada Kartu Menuju Sehat (KMS) Lansia 
Meja 3: Pengukuran tekanan darah dan pemeriksaan kesehatan

Meja 4: Pengobatan

Meja 5: Edukasi dan konseling

b. Penyediaan Kartu Menuju Sehat (KMS) Lansia

c. Senam lansia dan senam kaki diabetik

d. Pemeriksaan kesehatan

e. Edukasi dan konseling

Evaluasi pelaksanaan program melalui evaluasi terhadap keluhan sakit lansia dan frekuensi kunjungan ke posyandu: melalui Kartu Menuju Sehat (KMS) Lansia sebelum dan setelah kegiatan pengabdian dilakukan. Pada akhir pelaksanaan kegiatan PKM dilakukan evaluasi secara bersama antara tim pengabdian, kader kesehatan, puskesmas paccerakkang, dan perangkat kelurahan untuk merencanakan pengembangan program pada tahun berikutnya.

\section{Hasil}

\section{Pelatihan Kader Kesehatan}

Pelatihan kader kesehatan dilakukan pada tanggal 29 Juni 2018 di aula puskesmas Paccerakkang. Peserta pelatihan adalah kader kesehatan sejumlah 24 orang yang merupakan perwakilan dari 8 RW di kelurahan Paccerakkang. 1 RW mengutus 3 orang kader.

Pelatihan ini dihadiri oleh 4 pemateri atau narasumber, yaitu:

a. Kepala puskesmas paccerakkang (drg. Hj. Rafiqa), membawakan materi tentang peran dan fungsi kader kesehatan dalam posyandu lansia.

b. Ketua tim pengabdian (Arnis Puspitha R, prodi Ilmu Keperawatan), membawakan materi tentang tahapan pelaksanaan posyandu lansia sistem 5 meja.

c. Anggota tim pengabdian (Nurhaya Nurdin, prodi Ilmu Keperawatan), membawakan materi tantang tata cara pengisian KMS lansia.

d. Anggota pengabdian (Umniyah Saleh, prodi Psikologi), membawakan materi tentang teknik penyuluhan dan konseling pada lansia.

Pelatihan juga dihadiri oleh oleh kedua mitra yaitu Lurah Paccerakkang dan Kepala Puskesmas Paccerakkang. 
Perubahan dan kondisi kelompok sasaran sebelum dan setelah pelatihan dievaluasi secara formatif menunjukan antusiasme, disiplin dan motivasi untuk memperdalam pengetahuan dan mencari informasi yang relevan tentang masalah kesehatan yang dihadapi.

\section{Pembentukan Kelompok Kerja (Pokja) Lansia}

Kader kesehatan yang telah dilatih selanjutnya menjadi Pokja Lansia yang bertugas proaktif mendampingi lansia di wilayah RW-nya masing-masing. Selain itu, pokja juga bertugas memfasilitasi lansia yang membutuhkan pelayanan kesehatan, misalnya mengantar lansia ke puskesmas jika lansia tersebut butuh pengobatan tetapi tidak mampu menjangkau fasilitas pelayanan kesehatan. Pokja juga mengunjungi lansia secara door to door jika lansia tidak bisa ke posyandu atau puskesmas, dan melaporkan datanya ke petugas kesehatan.

\section{Pendampingan Posyandu Lansia}

Pendampingan posyandu lansia dilakukan mulai bulan Agustus di 8 RW di kelurahan Paccerakkang. Pengelolaan posyandu ini dilakukan oleh kader kesehatan yang telah dilatih, dan didampingi oleh tim pengabdian Unhas.

Tabel 3. Data kunjungan lansia ke posyandu lansia pada bulan Juli 2018

\begin{tabular}{|c|c|c|c|}
\hline $\begin{array}{c}\text { Lokasi } \\
(\mathbf{R W})\end{array}$ & $\begin{array}{c}\text { Nama } \\
\text { Posyandu } \\
\text { Lansia }\end{array}$ & $\begin{array}{c}\text { Jumlah } \\
\text { kunjungan lansia }\end{array}$ & Persentase \\
\hline RW-1 & Bougenville 1 & 33 orang & 18.33 \\
\hline RW-2 & Bougenville 2 & 18 orang & 10 \\
\hline RW-3A & Bougenville $3 \mathrm{~A}$ & 16 orang & 8.88 \\
\hline RW-3B & Bougenville $3 \mathrm{~B}$ & 18 orang & 10 \\
\hline RW-4 & Bougenville 4 & 24 orang & 13.33 \\
\hline RW-5 & Bougenville 5 & 20 orang & 11.11 \\
\hline RW-6 & Bougenville 6 & 27 orang & 15 \\
\hline RW-7 & Bougenville 7 & 24 orang & 13.33 \\
\hline \multicolumn{2}{|r|}{ Total kunjungan } & 180 orang & 100 \\
\hline
\end{tabular}

Pada posyandu lansia ini, diterapkan posyandu model/sistem 5 meja, dengan urutan sebagai berikut:

a. Meja 1 : Pendaftaran lansia

Pada meja 1, lansia yang datang ke posyandu lansia didaftarkan di buku registrasi lansia oleh kader kesehatan yang telah dilatih. Data lansia berupa nama, usia, jenis kelamin, 
pendidikan, pekerjaan, status pernikahan, teman serumah, keluhan saat ini dan riwayat alergi dicatat pada Kartu Menuju Sehat (KMS) lansia. Setelah itu, lansia berpindah meja ke meja 2.

b. Meja 2 : Pengukuran berat badan dan tinggi badan

Pada meja 2, lansia diukur berat badan dan tinggi badannya untuk mengetahui status gizi lansia.

Menilai status gizi pada lansia memerlukan metode pengukuran yang sesuai dengan perubahan yang terjadi pada struktur tubuh, komposisi tubuh serta penurunan fungsi organorgan tubuh. Metode yang bisa dilakukan pada pengukuran status gizi pada lansia adalah dengan menggunakan Mini Nutritional Assessment (MNA). Pada pengukuran dengan menggunakan MNA ini, pengukuran antropometri menjadi poin yang diukur.

Mini Nutritional Assessment (MNA) merupakan salah satu alat ukur yang digunakan untuk menskrining status gizi pada lansia. Hal ini dilakukan untuk mengetahui apakah seorang lansia mempunyai resiko mengalami malnutrisi akibat penyakit yang diderita dan atau perawatan di rumah sakit. MNA ini banyak digunakan karena sangat sederhana dan mudah dalam pelaksanaannya.

Khusus pada penilaian status gizi lansia berdasarkan Mini Nutritional Assessment, yang diukur dengan menggunakan metode antropometri adalah sebagai berikut :

\section{1) Berat Badan}

Berat badan merupakan gambaran massa jaringan termasuk cairan tubuh. Pengukuran berat badan ini paling sering digunakan untuk berbagai kelompok usia karena pengukuran berat badan ini juga dapat digunakan sebagai indikator status gizi pada saat skrining gizi dilakukan. Hal ini disebabkan karena berat badan sangat sensitive terhadap berbagai perubahan komposisi tubuh, sehingga penurunan atau kenaikan berat badan ini berkaitan erat dengan komposisi tubuh.

\section{2) Tinggi Badan}

Tinggi badan merupakan hasil pertumbuhan kumulatif sejak lahir sehingga parameter ini dapat memberikan gambaran mengenai riwayat status gizi masa lalu. Tinggi badan ini diukur dengan menggunakan alat ukur dengan menggunakan alat pengukuran seperti microtoise dengan ketepatan $1 \mathrm{~cm}$. 


\section{3) Indeks Massa Tubuh (IMT)}

Indeks Massa Tubuh (IMT) atau biasa dikenal dengan Body Mass Index (BMI) merupakan alat ukur yang sering digunakan untuk mengetahui kekurangan dan kelebihan berat badan seseorang. Dimana IMT ini merupakan alat yang sederhana untuk memantau status gizi orang dewasa khususnya yang berkaitan dengan kekurangan dan kelebihan berat badan, maka mempertahankan berat badan normal memungkinkan seseorang dapat mencapai usia harapan hidup lebih panjang.

c. Meja 3 : Pengukuran tekanan darah, gula darah, asam urat, dan kolesterol

Pada meja 3, dilakukan pengukuran tekanan darah lansia menggunakan sphygmomanometer (tensimeter) dan stetoskop. Kegiatan ini bertujuan untuk mengetahui tekanan darah lansia, sehingga hipertensi bisa diatasi dan risiko kematian atau penyakit akibat tingginya TD bisa diturunkan. Selain itu, juga dilakukan pemeriksaan gula darah untuk mengetahui apakah lansia mengalami diabetes mellitus; pemeriksaan asam urat, dan kolesterol.

d. Meja 4 : Pelayanan Kesehatan

Pada meja 4, petugas kesehatan memberikan obat-obatan kepada lansia yang menderita sakit. Sebagian besar lansia menderita hipertensi, rematik, diabetes mellitus, batuk, dan bahkan ada yang post stroke.

e. Meja 5 : Penyuluhan atau konseling

Paa meja 5, lansia diberikan penyuluhan tentang penyakit-penyakit yang dialami, seperti penyuluhan tentang hipertensi, rematik, diabetes mellitus, dan dilakukan terapi aktifitas kelompok.

\section{Pengaktifan Senam Lansia}

Senam lansia adalah olahraga ringan dan mudah dilakukan, tidak memberatkan yang diterapkan pada lansia. Aktifitas olahraga ini akan membantu tubuh agar tetap bugar dan segar karena melatih tulang tetap kuat, mendorong jantung bekerja optimal dan membantu menghilangkan radikal bebas yang berkeliaran di tubuh.

Kader kesehatan di masing-masing RW dilatih untuk menjadi instruktur senam lansia, sehingga senam lansia bisa diaktifkan setiap minggu. Setelah rutin melakukan senam lansia, 
lansia merasa lebih sehat dan lebih bugar. Selain itu, senam lansia juga berdampak pada peningkatan kualitas dan kuantitas tidur lansia, menormalkan tekanan darah, berkurangnya keluhan kesemutan pada bagian tangan dan kaki.

Lansia juga mengatakan setelah senam perasaannya lebih senang, stres berkurang, dan hidupnya lebih bersemangat, karena sesama lansia saling bersosialisasi dan saling menambah keakraban.

\section{Edukasi Senam Kaki Diabetik sebagai Pengembangan Program Posyandu Lansia}

Salah satu aktifitas fisik yang juga dianjurkan secara rutin adalah Gerakan Senam Kaki Diabetes. Manfaat yang diharapkan dari gerakan kaki yang teratur dari senam kaki diabetes, adalah tidak terjadinya komplikasi yang sering terjadi pada kaki-kaki pasien DM seperti luka infeksi yang tidak sembuh dan menyebar. Cara melakukan gerakan senam kaki diabetes ini sangatlah mudah. Senam kaki diabetes bisa dilakukan di dalam maupun di luar ruangan. Tidak memerlukan waktu yang lama, karena hanya berlangsung sekitar 15-30 menit. Senam ini tidak memerlukan peralatan yang rumit, cukup dengan kursi dan sehelai koran bekas.

Senam kaki diabetik dilakukan sebagai program tambahan bagi para lansia yang menderita diabetes mellitus. Senam ini dilakukan di puskesmas dan di posyandu lansia di bawah bimbingan tim pengabdian Unhas. Petugas kesehatan juga dilatih sehingga ke depannya bisa dilakukan secara mandiri dan bisa mengedukasi lebih banyak lansia.

Hasil pengabdian masyarakat menunjukkan bahwa para kader kesehatan dan masyarakat sangat antusias dengan adanya pelatihan kader, pendampingan posyandu lansia, penyuluhan kesehatan, senam lansia, dan senam kaki diabetik. Selain itu, meningkatnya pengetahuan dan keterampilan kader dalam pengelolaan posyandu lansia, meningkatnya motivasi lansia untuk mengikuti kegiatan posyandu lansia di RW masing-masing.

\section{Pembahasan}

Pendidikan kesehatan penatalaksanaan DM dengan melibatkan kader juga sangat penting bagi anggota masyarakat yang lainnya, mengingat Diabetes Melitus merupakan penyakit yang beresiko bagi anggota masyarakat yang lainnya. Selain itu, Diabetes Melitus merupakan penyakit kronis yang menurunkan kemampuan dari pasien, sehingga jika kader dilibatkan dalam program 
edukasi ini, masyarakat dapat membantu melakukan penatalaksanaan DM dan meningkatkan perilaku perawatan diri pada pasien saat kondisi pasien mulai memburuk (Sari, et.al. 2018).

Selain itu kolaborasi inter personal sangat diperlukan dalam membangun kesehatan, baik dari petugas kesehatan maupun dari pimpinan local di masyarakat. Selanjutnya kebijakan yang diterapkan secara aplikatif dalam menunjang kesehatan lansia harus dilakukan secara teratur dan dipelihara dalam kegiatan sehari hari (Rahayuwati, et.al, 2016).

Berdasarkan hasil PKM, juga menunjukkan agar program lebih langgeng perlu diupayakan suatu Model Promosi Kesehatan yang melibatkan keluarga, kelompok dan pemberi layanan kesehatan sebagai sumber interpersonal yang penting yang mempengaruhi, menambah atau mengurangi keinginan untuk melakukan upaya kesehatan mandiri. Model ini dapat digunakan untuk mendukung pelakasanaan program kesehatan lansia. Selain itu pengaruh interpersonal atau dukungan dari orang-orang yang berarti juga akan mempengaruhi perilaku pencegahan secara umum maupun spesifik, seperti pada kesehatan lansia (Rahayuwati, 2018).

\section{Simpulan}

Program Kemitraan Masyarakat (PKM) berupa pelatihan dan pendampingan posyandu lansia memberikan manfaat yang sangat besar bagi para lansia di kelurahan Paccerakkang. Melalui kegiatan ini, lansia mendapatkan pelayanan kesehatan dasar, meningkatkan pengetahuan lansia tentang kondisi kesehatannya, dan memotivasi lansia untuk rutin mengunjungi posyandu lansia setiap bulan. Kegiatan ini juga menambah wawasan kader kesehatan tentang pengelolaan posyandu lansia.

\section{Ucapan Terima Kasih}

Terima kasih kepada Direktorat Riset dan Pengabdian kepada Masyarakat (DRPM) Kementerian Riset, Teknologi, dan Pendidikan Tinggi yang telah mendanai kegiatan ini melalui Hibah Program Kemitraan Masyarakat (PKM) pendanaan tahun 2018.

\section{Daftar Pustaka}

Badan Pusat Statistik. 2015. Statistik Penduduk Usia Lanjut 2014, Jakarta: BPS. Data Kelurahan Paccerakkan Kota Makassar, 2016. 
Data Puskesmas Paccerakkan Kota Makassar, 2016.

Kementerian Kesehatan Republik Indonesia. 2016. Pusat Data dan Informasi Kementerian Kesehatan RI. Situasi Lanjut Usia di Indonesia, Jakarta.

Kementerian Kesehatan Republik Indonesia. 2017. Penilaian Status Gizi. Jakarta, Badan Pengembangan dan Pemberdayaan Sumber Daya Manusia Kesehatan.

Maryam, R \& Siti. 2011, Mengenal Usia Lanjut, Jakarta, Salemba Medika.

Rahayuwati, L., Ermiati, E., \& Trisyani, M. (2016). Process Evaluation: Standard, Effectiveness, Efficiency and Sustainability of Maternity Nursing Care. Jurnal Keperawatan Padjadjaran, 4(2).

Rahayuwati, L., Nurhidayah, I., Ibrahim, K., \& Setyorini, D. (2018). Pendidikan dan Promosi Kesehatan tentang Pencegahan Penyakit Kanker melalui Pilihan Jajan pada Siswa-Siswi Sekolah Dasar serta mengenali Potensi Masyarakat dalam Peningkatan Kesehatan. Media Karya Kesehatan, 1(2).

Sari, C. W. M., \& Yamin, A. (2018). Edukasi Berbasis Masyarakat untuk Deteksi Dini Diabetes Melitus Tipe 2. Media Karya Kesehatan, 1(1). 